\title{
Promoting Oral Language Skills in Preschool Children through Sociodramatic Play in the Classroom
}

\author{
P.L.N. Randima Rajapaksha \\ Department of Early Childhood and Primary Education \\ Faculty of Education, The Open University of Sri Lanka Nawala, Nugegoda, Sri Lanka \\ E-mail: plran@ou.ac.lk
}

Received: 18-11-2015

doi:10.7575/aiac.ijels.v.4n.1p.15
Accepted: 25-01-2016

URL: http://dx.doi.org/10.7575/aiac.ijels.v.4n.1p.15

Published: $31-01-2016$

\begin{abstract}
Children best learn language through playful learning experiences in the preschool classroom. The present study focused on developing oral language skills in preschool children through a sociodramatic play intervention. The study employed a case study design under qualitative approach. The researcher conducted a sociodramatic play intervention collaboratively with the class teacher for a group of 10 children selected utilizing purposive sampling method in a preschool classroom. The intervention was conducted in a preschool located in Colombo, Sri Lanka for 3 weeks. The observation, interview and reflective journal were the instrument used to collect data. The observation carried under two criteria namely, ability to initiate a conversation and ability to respond in a conversation revealed that the sociodramatic play intervention created many opportunities to develop oral language skills in the children than the regular classroom activities. The sociodramatic play activities enhanced children's oral language skills while creating a language rich playful learning experiences.
\end{abstract}

Keywords: Language development, Early childhood education, Sociodramatic play

\section{Introduction}

Play offers the best learning experiences and remains a priority in early childhood education (Moyles, 2005). Proponents of early childhood education believe children learn naturally through play (Puteh \& Ali, 2013). Sri Lankan National Policy on Early Childhood Care and Development (2004) emphasizes the importance of integrating play into the preschool.

The play has been called "the work of children" because it is through play that children learn how to interact in their environment, discover their interests, and acquire cognitive, motor, speech, language, and social-emotional skill (American Academy of Pediatrics, 2007). Play can make important contributions to the learning of language (Weisberg, Zosh, Hirsh-Pasek, \& Golinkoff, 2013). Many of these investigations find that language thrives when children are interacting with adults and peers in a playful manner (Hirsh-Pasek \& Golinkoff, 2003; Smith, 2010; Vygotsky, 1967; Zigler \& Bishop-Josef, 2004).

The sociodramatic play is used to refer to a voluntary social role-taking involving two or more children (Levy, 1986). Sociodramatic play occurs when groups of children adopt roles and act out make-believe stories and situations (Johnson et al., 2005). Smilansky (1968) identifies five components in socio-dramatic play: role-playing, make-believe transformations, social interactions, verbal communication, and persistence. Through sociodramatic play, children can gain the early language skills essential for success in our society (Paley, 2004). Research has documented firm connections between this advanced form of play and oral development (Singer, Golinkoff, \& Hirsh-Pasek, 2006). Vygotsky (1966) attributed a key role in the development of language and thought to make-believe play, which he described as a particular feature of the preschool age with profound implications in future development. Vygotsky (1966) further argued that play contains all the developmental tendencies in a condensed form (physical, cognitive, emotional) and thus creates a zone of proximal development that pulls the child forward. Play activity is essential in the preschool years because it leads to development, abstract thinking, self-awareness, and self-regulation (Singer, Golinkoff \& Hirsh-Pasek, 2006). For this reason, this study focuses on preschoolers.

Currently, many educators of young children admit to seeing decreases in developmentally appropriate oral language instruction in preschools (Bluiett, 2009). Time is spent on academic concepts instead of on building and facilitating language growth; even assessment of young children's language is confined to vocabulary and letter names (Kirkland \& Patterson, 2005).

Similarly, the Sri Lankan National Policy on Early Childhood Care and Development (2004) stated that very often preschool experiences become formal experiences because of the notion that preschool should prepare the child for 
primary school. As a result of the increase in high-stakes testing and the narrowing of the curriculum, the sociodramatic play is forfeited among many preschool classrooms (Neuman \& Roskos, 2005).

Due to the decrease of play in the preschool classroom, there is a need to explore sociodramatic play, oral language, and the interactions of both in order to add to the pool of early childhood education research in Sri Lanka. This research investigated how sociodramatic play is used to promote oral language skills in preschool children in the context of the Sri Lankan preschool classroom. The findings from this research may provide preschool teachers with research-based information that assist them in combining oral language experiences with sociodramatic play to create meaningful experiences that encourage developmentally appropriate instruction through sociodramatic play.

Based on the problem identified, the research questions are:

1. How do preschool children develop the ability to initiate a conversation through the sociodramatic play intervention implemented in the classroom?

2. How do preschool children develop the ability to respond appropriately in a conversation through the sociodramatic play intervention implemented in the classroom?

\subsection{Sociodramatic play and Language development in children}

Language is a verbal system. It consists of words and rules for organizing words and changing them (Roskos, Tabors, \& Lenhart, 2004). Oral language comprehension is the ability to listen to spoken language and respond with understanding (Roskos et al., 2004).

Piaget (1962) stressed the importance of play in the child's cognitive development as a way of assimilating new information and consolidating past experience through symbolic means. Piaget recognized that play is not only for fun, but can be the essential learning tools for developing language. A child learns to use language and represent objects by images and words. Teachers, therefore, need to be aware of the child's abilities and level of development in order to set appropriate tasks (Puteh \& Ali, 2013).

More so than Piaget, Vygotsky (1978) distinguishes between development and learning with the 'zone of proximal development' (ZPD). According to him, 'the zone of proximal development is the distance between the actual developmental level as determined by independent problem solving and the level of potential development as determined through problem solving under adult guidance or in collaboration with more capable peers. Vygotsky (1978, 1986) emphasized the importance of language in learning and view learning as a reflection of the culture and community in which students live. According to Vygotsky, language helps to organize thought, and children use language to learn as well as to communicate and share experiences with others (Bluiett, 2009). In every culture, language learning takes place through everyday interactions and shared experiences between adult and child (Vygotsky, 1986). These interactions emerge in play situations which create contexts for cultural and linguistic learning, exploration, and socialization (Galeano, 2011; Paugh, 2005). Children learn to talk through social interactions and to read and write through interactions with literate children and adults (Dyson, 1993; Harste, 1990) within the ZPD.

Research revealed that participation in sociodramatic play increases oral language use (Snow et al., 1998) and it becomes more cohesive in sociodramatic play than in other types of play (Pellegrini \& Galda, 1993). Because such play typically requires a good deal of negotiation among the children as they determine who will play what role, how the storyline will unfold, whether events are unfolding as planned, and so on (Scanlon, Anderson, \& Sweeney, 2010)

Sociodramatic play involves great deal of oral language skills when children assume adult roles, become the characters they invent, and verbally act out dramatizations based on these characters (Cook, 2000; Corsaro, 2003; McCafferty \& Steven, 2002; Sullivan, 2000).

When children in real life settings are faced with a problem that requires the use of language and they are motivated to use and learn language; for instance, when children see adults writing checks, making a grocery list, reading a menu, reading a cookbook, or reading directions, they see through these experiences the necessity of literacy and language and find learning about both of these are useful for achieving daily goals (Bluiett, 2009). These common real experiences of going to a supermarket or some other place in the community, or to school, emerge themes for sociodramatic play (Bluiett, 2009; Garvey, 1990).

In sociodramatic play, children are required to engage in two forms of communication: communication about the play ("meta-communication") while retaining their own real-life identities, the pretenders negotiate the roles and scene (or "script") to be enacted, and communication which is held within the play mode, where the children relate to one another in the roles they have agreed to perform (Fein, 1979, Garvey \& Berndt, 1977). Therefore children use elaborated language (Pelligrini, 1982, 1984). They define pronouns linguistically, modified nouns with adjectives, and used causal and temporal conjunctions in order to make their imaginative suggestions intelligible to their play partners. Moreover, in the process of negotiating pretend scripts and incorporating their partner's suggestions, young children learn to accommodate different perspectives (Bluiett, 2009).

In addition, children learn how to use gestures and words to designate real events and/or persons (Pellegrini, 1983) in sociodramatic play. This may take away the nervous tension that can impede language learning, and help to notice how to produce a sound, use grammatical structures, or master the social use of language (Robels, 2009). Therefore, in sociodramatic play, language may take on the simplest forms such as sounds or utterances or it may be more 
sophisticated which creates one of the important contexts in the preschool classroom that supports children's oral language development (Smilansky, 1968; Vygotsky, 1967; Christie \& Enz, 1992; Combs, 2010; Weisberg, Zosh, HirshPasek, \& Golinkoff, 2013). However, playing with literacy objects and routines in socio-dramatic play might affect children's interest in explicit teaching of language and literacy in teacher-directed contexts, perhaps making them more interesting to young children (Morrow \& Schickedanz, 2006).

\section{Method}

This study employed qualitative approach utilizing case study research design. The study took place in a preschool conducted by an institution in the Colombo district in Sri Lanka. The researcher conducted a sociodramatic play intervention collaboratively with the class teacher for about 3 weeks. 12 sessions were included in the intervention under three themes; Shop, Market and Dispensary. One session on sociodramatic play lasted for 20-30 minutes. The observations were conducted during three weeks of duration. The set up was organized with several play props and materials appropriately to each theme. Both children and teacher had not previous experiences on using sociodramatic play in the classroom for the development of oral language skills. Therefore, the teacher who conducted the play sessions was given prior instructions on facilitating the sociodramatic play for the development of oral language skills.

\subsection{Participants}

There were 50 children from both lower and upper class in the preschool. This was taken as the target population of the study. Among the target population 10 children who were in the exploration level in relation to oral language skills were taken as the sample. One preschool teacher was also included in the sample. Among the 10 children, there were five boys and five girls. Among them, 3 boys (ML, MN and HK) and 3 girls (KV, NT and TU) were in the 3-4 age category and 2 boys (HR and SV) and 2 girls (SS and SN) were in the 4-5 age category. All the participants were selected purposively. Before selecting the sample, the researcher conducted a preliminary observation on language activities and the level of oral language skills of all children.

As mentioned in the Starting Light: Early Childhood Development Standards for Sri Lankan Children from 3-5 years (2014), the oral language skills were observed under two criteria namely: the children's ability to initiate conversation and children's ability to engage in conversation appropriately. Their abilities were rated as not engaging, exploring, developing and building. The exploring level was identified as children respond to simple questions with a simple reply and make one comment. Developing level was identified as children respond to conversation with appropriate actions and make more than one comment. Building level was identified as children respond to questions with appropriate actions and comments and make comments and ask questions in the conversation. Not engaging was children who do not perform any of these levels. Among the four categories, 10 children who were in the exploration level were selected purposively as the sample. Before the intervention, the consent of the parents of children and the teacher was taken. All 10 children were given a name code. The researcher didn't include any identification of children in the research.

\subsection{Data Collection Techniques}

The researcher employed three instruments in this study. The main instrument was observations. The same observation schedule which was used during the preliminary observation, utilized during the sociodramatic play intervention to measure the language level of children. The observations were focused on two subcategories, namely the children's ability to initiate conversation and children's ability to engage in conversation appropriately. The level of children's oral language skills was rated based on four ratings namely not engaging, exploring, developing and building.

All the observations were videotaped and recorded in the field notes (Cohen et al., 2003). The researcher kept field notes after each session in the intervention. These field notes included a description of the physical setting, the scene, and characters, behaviors of the children, and their oral language skills.

Apart from the observations, the teacher was asked to maintain a reflective journal focusing on children's participation in sociodramatic play and children's development of oral language skills.

In addition, an interview was conducted after the intervention as a meaning-making process, with the aim of exploring the teacher's views on the sociodramatic play intervention and the development of oral language skills of children.

\subsection{Data Analysis}

The descriptive analysis method was employed for analysis of the data. All the videotapes were viewed several times in order to document the conversations focusing each child in relation to the research questions. The data gathered via the instruments were triangulated under the research questions in order to establish reliability. While reading all the collected data the similarities were identified. According to the similarities the data were categorized according to the research questions. Finally, the data were descriptively analyzed under the themes developed based on the research questions. The researcher included the statements of the teacher from the interviews, extractions from her reflective journal and conversations took place among children in the report in order to maintain the credibility and dependability of the findings. 


\section{Result and Discussion}

The data gathered in this research addressed the research question 'How can sociodramatic play be used to develop oral language skills in preschool children through an intervention implemented in the classroom?' Thus, the results are discussed under the two themes according to the research questions.

\subsection{Children's Ability to Initiate a Conversation during the sociodramatic play intervention}

Initially the level of oral language skills in children was in the exploring level. The sociodramatic play intervention created many opportunities to engage in verbal exchanges with each other as mentioned by Ervin-Tripp (1991). The following teacher's reflection further confirms the opportunities for verbal exchange in the sociodramatic play intervention.

In this play many children started to talk and express their ideas when they imitated the role than in their regular classroom activities. I felt happy to see that the children who didn't talk much in the other activities tended to talk in this play. (Teacher's reflective journal, 28.11.2014)

At the beginning of the intervention the children's ability to initiate a conversation in the play themes was less. This was due to their lower participation in the sociodramaticc play activities. However, majority of children's ability to initiate a conversation was improved from the exploring level to the developing and building level during the intervention. Among the 10 children it was identified that, ML, SS and HR improved their ability to initiate a conversation up to building level. ML and HR showed better engagement in initiating conversation from the beginning.

During the first theme (Shop) majority of children didn't participate much in conversation. The teacher always started the conversation in order to make them engage in it. The following conversation which emerged during the first theme shows the less ability of children in initiating a conversation at the beginning.

During the first theme the teacher became the mother, ML was the shop owner and KV the helper.

Session 1- Shop

Teacher: Mudalali we came to buy some clothes for us. Can you help us?

ML: OK

Teacher: Let's see a frock for my daughter (SS).

ML: Take this (giving a frock)

Teacher puts the frock on SS

Teacher: Mudalali, this is too small.

$\mathrm{KV}$ : Ok, try this one (shows a skirt)

ML: Try a skirt

Teacher gives a skirt to SS.

Teacher: SV did you look for a shirt?

SV had chosen a red shirt.

SV: This one

According to the above conversation, it was clearly seen that children hesitated to initiate a conversation at the beginning. This was apparently evident in MN, KV, SN, SS and NT except ML. According to the above conversation it can be revealed that ML was more interested in initiating a conversation than the others. Apart from ML it was seen that KV made a slight attempt to initiate a conversation with ML.

Moreover, it was apparent during the beginning themes in the intervention that children used bodily expressions to convey their ideas (Robels, 2009). For example it was observed that in the Shop theme, MN didn't try to initiate a conversation. Once the teacher asked him whether he liked the shirt he wore, he didn't express his response; instead he nodded his head as if to say he liked it.

Further it was also demonstrated that the use of simplest forms of verbal expression took away the nervous tension (Robels, 2009). This was clearly evident when the second theme was introduced. It was seen that during the first theme the children were a little nervous to talk. When the Market theme was implemented, children showed more interest in it. The tendency to initiate conversation improved gradually as well.

In the Market theme, the children were given many roles to play. At the start the teacher had to give directions to children to go and buy clothes, shoes, and accessories. Thus, the children were given an opportunity to initiate conversation. This ability was seen up to a certain extent in ML, SS, HR, KV and NT. They volunteered to start imitating their roles and once they obtained the capacity to imitate their role, their ability to initiate conversation slightly increased.

The following conversation in the Market theme can be taken as an instance of their gradual improvement in initiating a conversation. In this session of Market theme, HR was the owner of a Shoe shop. NT was a customer. 
Session 2 - Market

HR: 'Please come to buy shoes.'

NT: 'I want a pair of shoe'

HR: 'Ok try this.'

NT puts on a pair of shoe.

HR: 'That is good. You take it.'

Session 3 - Market

$\mathrm{KV}$ was also able to engage in a conversation. She was a customer. And NT was the accessories shop owner.

$\mathrm{KV}$ : 'Give me a necklace'.

NT: 'Take a look at this'

$\mathrm{KV}$ starts to choose necklaces

SS: 'Mudalali, Do you have bangles? This colour' (Showing a red bangle)

NT: 'Yes.'

Thus, during the Market theme some children were able to improve their ability to initiate a conversation. Yet HK, MN, $\mathrm{SN}, \mathrm{TU}$ and SV were at the lower level.

However, when the children's participation in the sociodramatic play increased gradually their ability to initiate a conversation too improve simultaneously. When the intervention introduced the Dispensary theme, a remarkable change was seen in the children's ability to initiate a conversation. It was observed that during this theme almost all children were able to improve their ability to initiate conversation up to the developing level. ML, HR, and, SS were able to develop their ability up to the building level.

As usual at the beginning the teacher had to give slight guidance until they obtained the skills to participate in their roles. However, when children moved to the third and fourth sessions they were able to initiate conversation without the teacher's direction.

The following conversation is an example of their improvement in the ability to initiate a conversation during the first session of the Dispensary theme,

Session 1 - Dispensary

Teacher: SS your daughter is sick. Isn't she?

ML: (SS was silent) she has a fever.

Teacher: Yes

As in the above conversation, SS was a little shy to imitate the role of mother at the beginning. When SS came with KV (her daughter) to the doctor (ML), he silently looked at her until SS started the conversation. After the teacher's guidance ML started to question them.

It was observed that during the third session that ML was able to initiate a conversation without the teacher's assist. The following conversation is an example for children's gradual improvement of the ability to initiate a conversation.

Session 3- Dispensary

ML was the doctor, HR was the father, SS was the nurse and MN was the patient.

ML: What is the matter?

HR: My son has fever, cough and he vomited.

ML starts to check MN.

ML: Breath fast.

Then he writes a prescription and gave HR

ML: Sign here

HR: What?

SS: Sign here in the paper

Teacher: We need to check him more isn't it doctor? Nurse aunty, help the doctor to put him on the bed.

ML: Go to the bed. (Tells to MN) MN is silent.

HR: Go to bed (says tapping MN)

According to the above conversation it was seen that the children gained the ability to initiate a conversation with their improvement in participation in the sociodramatic play. Further it was observed that some children were a little reluctant to initiate a conversation in the sociodramatic play when they were given a leading role such as the doctor. 
This was apparent in HR, NT, KV, TU and HK. However SS and ML didn't show this diffidence. The following teacher's reflection further confirms the ability to initiate a conversation according to different roles.

When the opportunity came to HR to become the doctor he was a little nervous to start the conversation at first. In the role of father he was naturally able to initiate a conversation. This was again seen in NT, KV, $\mathrm{TU}$, and $\mathrm{HK}$ in their doctor role. I felt that they are a little shy to initiate a conversation. So I had to direct them more in the doctor role than in the other roles. However, when they played the roles of nurse, patient, father or mother they were quite able to initiate a conversation. (Teacher's reflective journal, 01.12.2014)

It was identified that according to the nature of the role the children's ability to initiate a conversation differed. The following conversation among NT, TU and SS in the Dispensary theme further illustrates this difference.

Session 3 - Dispensary

NT was the mother, TU was the patient and SS was the Doctor.

NT: Doctor, my daughter has fever.

SS: Breathe fast. (Checking the patient with the stethoscope)

SS: Go to the bed.

She starts giving injections and giving medicines to drink.

NT: Look... What happed to my daughter?

In session 4, NT was the nurse. KV was another nurse. HR was the father, SN was the patient and SS was the doctor. $\mathrm{SN}$ was on the bed. SS was giving injections.

NT: Look. She has another wound here.

She starts to put some medicine on it.

NT: KV you put medicine here.

According to the above conversation it was demonstrated that in the mother's role NT's ability to initiate a conversation increased. Therefore, it could be seen that the children's ability to initiate a conversation varied according to the theme and the role they played.

Moreover it was observed that the improvement in their ability to initiate a conversation was seen in the Dispensary theme. The highest participation too of children in the sociodramatic play intervention was recorded in the same theme. Therefore it was clearly identified that when children gained interest and participated in the sociodramatic play more, they got opportunities to improve their ability to initiate a conversation too. This was further confirmed in the following field note.

I think now the children are more used to the sociodramatic play than at the beginning. So now they are talking part more and exchanging their ideas with each other. So the interaction has improved. I saw a very good improvement in ML, SS, NT, HR and KV‘s verbal communications. (Field note, 08. 12. 2014)

Accordingly when children reached the final theme, a majority of them showed an improvement in their ability to initiate a conversation though the levels were different.

As Bluiett (2009) states, play situations have strong learning potential because they provide opportunities for children to use language to build and extend meanings, especially when it is initiated by the child. This was clearly evident in the present study that when children gained the ability to initiate a conversation there were many opportunities for them to converse with each other and interact freely.

Therefore, it was identified that the sociodramatic play intervention made a positive impact on the majority of children to improve their ability to initiate a conversation to a certain extent from the beginning to end of the intervention simultaneously with their improvement in participation in the sociodramatic play.

\subsection{Children's Ability to Respond Appropriately in Conversation during the sociodramatic play intervention}

It was clearly recognized that though some children showed less improvement in the ability to initiate a conversation, a majority of children showed a significant ability to respond in conversation from the beginning. This positive tendency was identified from the very first theme. The following conversation in the first theme shows children's engagement in responding in a conversation.

Session 2- Shop

Teacher: Let's see a frock for my daughter (SS).

ML: $\quad$ Take this (giving a frock)

Teacher puts the frock on SS

Teacher: Mudalali this is too small.

$\mathrm{KV}$ : Ok try this one (shows a skirt)

ML: Try a skirt 
Teacher gives a skirt to SS.

According to the above conversation, the ability to respond in conversation between ML and KV was demonstrated. Further it was noticed that SS didn't try to respond to what the teacher was talking about with ML. However, during the Market theme, this situation was changed. SS started to respond in the conversation better. It was seen that she liked the role of the mother better than that of daughter. The following conversation is an instance which marks SS's improvement in her ability to respond in a conversation in the Market theme.

Session 3- Market

Once she comes to the cloth shop,

SS: I need a frock.

ML: Take this. (Gives a blue color frock)

$\mathrm{SS}$ : How much is this?

ML: Rs 5.

She goes to the accessories shop

$\mathrm{KV}$ : Give me a necklace.

NT: Take a look at this

KV starts to choose necklaces

SS: Mudalali Do you have bangles? This colour (Showing a red bangle)

NT: Yes

SS: I need this one also (Showing a necklace)

NT: OK

$\mathrm{SS}$ : How much is this?

NT: Rs. 350

$\mathrm{SN}$ I need this bangle. How much?

NT: Rs. 350

They are busy with choosing and buying accessories.

Accordingly it was seen that with regard to the above conversation the children's ability to respond in conversation also varied with their interest in imitating the role. Moreover, it was observed that when children got used to the play they showed a greater tendency to respond in conversation. The above conversation again is an example for it. Yet, it was observed that the teacher directed some of them to respond in a conversation and to continue it. The following conversation in the Market theme provides further evidence.

Session 4- Market

Teacher: TU don't you want to buy a pair of shoe

TU smiles and goes HR who is the shoe shop owner.

TU: Give me this one (shows a pair of shoes)

She tries to put it on, but it is too small.

TU: This is small. (She gives it back and goes to her friends)

As indicated in the above conversation, both TU and HK were still at lower levels in this ability compared to the others. It could be that they engaged first in sociodramatic play in the Market theme. Therefore, those who didn't participate in the first theme showed less improvement in responding to conversation at first. However, gradually it could be seen that they showed better engagement in responding to conversation than initiating a conversation. The following reflection of the teacher further illustrates the children's gradual improvement in responding to a conversation.

Children had more engagement in today's session on Dispensary. They had engagement a lot in talking. So many children responded to conversation.( Teacher's reflective journal, 01.12.2014)

It was identified that a majority got opportunities to respond to conversation in the sociodramatic play intervention. When children like the role their ability to respond in the conversation increased showing that the specific roles taken by peers and by adults (Neuman \& Roskos, 1993) have an impact on their language during the play roles. This ability was clearly evident in the majority of children. For instance it was seen that ML and SS showed more engagement in both oral language skills when they imitated the role of the doctor, whereas NT and KV showed improvement in oral language skills in the role of the teacher. HR's best improvement was seen in oral language skills in the role of the father. MN, SV, HK and TU showed improvement in the oral language skills in the roles of nurse, customer and patient.

It was further demonstrated in this sociodramatic play intervention the children acquired many opportunities to improve their oral language skills in playful activity, as playfulness allows for opportunities to try out different ways in which 
the children could combine the elements of the language without having to worry too much about the consequences of making errors.

\section{Conclusion}

This research attempted to address the research question 'How can sociodramatic play be used to develop oral language skills in preschool children through an intervention implemented in the classroom?' The intervention implemented in one preschool classroom and there has limitations in terms of generalization. The sociodramatic play intervention implemented in the preschool classroom created a language rich environment and offered many opportunities to develop oral language skills in children particularly for children who communicate rarely in the classroom activities. The children's ability to respond in conversation develops from the beginning while the ability to initiating a conversation take more time and engagement in the play. The level of participation in the sociodramatic play intervention, children's interest on the imitative role, theme and the level of facilitation given by the teacher have an influence on the development of the oral language skills during the sociodramatic play intervention. Further the intervention explicated concrete pedagogic strategies for the teacher working with children in sociodramatic play to develop oral language skills. The intervention presented reliable evidences that children's sociodramatic play is both a medium and context for developing such playful context for the development of oral language skills in children. The conclusion made from this research will add more insight to the preschool teachers as well as to parents to encourage sociodramatic play to nourish oral language development in children. Further it opens for more investigations on sociodramatic play and language development due to the dearth of empirical literature in this area within the Sri Lankan context by re-valuing and re-centralizing the importance of sociodramatic play in the preschool classroom.

\section{Acknowledgements}

I would like to convey my sincere gratitude to Professor Manjula Vithanapathirana, Professor in Department of Educational Psychology, Faculty of Education, University of Colombo, Sri Lanka, for her guidance on completing this research.

\section{References}

American Academy of Pediatrics. (2007). Year 2007 position statement: principles and guidelines for early hearing detection and intervention programs. Pediatrics, 120(4), 898.

Bluiett, T.E. (2009). Sociodramatic play and the potentials of early language development of preschool children, (doctoral dissertation). http://acumen.lib.ua.edu/content/u0015/0000001/0000137/u0015_0000001_0000137.pdf

Christie, James F., \& Enz, Billie. (1992). The effects of literacy play interventions on preschoolers' play patterns and literacy development. Early Education and Development, 3(3), 205-220 EJ $447 \quad 691$. http://www.tandfonline.com/doi/abs/10.1207/s15566935eed0303_1\#.VUcdu_AQjK8

Cohen, L., Manion, L., \& Morrison, K. (2003). Research methods in Education. New York. Routledge Falmer.

Combs, S. G. P. (2010). The effects of information sharing and modeling on teacher talk and children's language during dramatic play. Dissertation Abstracts Inter-national Section B: The Sciences and Engineering, 70 (2010-99040-016).

Cook, G. (2000). Language Play, Language Learning. Oxford: Oxford University Press, pp. 235, ISBN 0194421538. https://muldisc.files.wordpress.com/2011/03/review-by-chf-of-cook-2000-in-1l-distributed-version.pdf

Corsaro, W. A. (2003). We're Friends, right? Inside Kids' culture. Washington D.C., Joseph Henry Press.

Dyson, A. H. (1993) Research currents: Diversity, social responsibility, and the story of literacy development. Language Arts, 67, 192-206.

Ervin-Tripp, S. (1991). Play in language development. In B. Scales, M. Almy, A. Nicolopoulou, \& S. Ervin-Tripp (Eds.), Play and the social context of development in early care and education, (pp. 84-97). New York: Teachers College Press.

Fein, G. (1979). Play and the acquisition of symbols. In L. Katz (Ed.), Current topics in early childhood education. Norwood, NJ: Ablex.

Galeano, R. (2011). Scaffolding Productive Language Skills through Sociodramatic Play, American journal of Play. Winter, 324-355. http:/www.journalofplay.org/sites/www.journalofplay.org/files/pdf-articles/3-3-article-galeanoscaffolding-productive-language-skills.pdf

Garvey, C. (1990). Play. Cambridge, MA: Harvard University Press.

Garvey, C., \& Berndt. R. (1977). Organization of pretend play. Catalogue of Selected Documents in Psychology, 13, 246-252. eric.ed.gov/?id=ED114891

Harste, J. (1990). Whole language: getting the act together. Education Digest, 57, 45-50.

http://connection.ebscohost.com/c/articles/9201061144/whole-language-getting-act-together

Hirsh-Pasek, K., \& Golinkoff, R. (2003). Einstein never used flash cards: How our children really learn--and why they need to play more and memorize less. Rodale.

Johnson, J., Christie, J., \& Wardle, F. (2005). Play, development, and early education. New York: Allyn \& Bacon. 
Kirkland L. D. and Patterson J. (2005). Developing Oral Language in Primary Classrooms. Early Childhood Education Journal, 32(6), 391-395. DOI:10.1007/510643-005-0009-3

Levy, H. (1986). Meeting the needs of all students through differentiated instruction: Helping every child reach and exceed standards. The Clearing House, 81, 161-164. www.wou.edu/ tbolsta/web/texbook/24_Meeting_the_Needs.pdf

McCafferty \& Steven G. (2002). Gesture and creating zones of proximal development for second language learning. Modern Language Journal,86, 192-203. www.jstor.org/stable/1192921

Ministry of Child Development and Woman Empower; Child Secretariat; (2004). National Policy on Early Childhood Care and Development.

Morrow, L. \& Schickedanz, J. (2006). The relationship between sociodramatic play and literacy development. In S. Neuman \& D. Dickinson (Eds.), Handbook of early literacy research (Vol. 2, pp. 269-280). New York: Guilford Press

Moyles, J., (2005). The excellence of play. New York: Open Press University

Neuman, S. B., \& Roskos, K. (1993). Descriptive observations of adults' facilitation of literacy in young children's play. Early Childhood Research Quarterly, 8, 77-97. www.sciencedirect.com/science/article/pii/S0885200605800997

Neuman, S. B., \& Roskos, K. (2005). Whatever happened to developmentary appropriate practice in early literacy? Young Children. 60(04), 22-27.10

Paley, V. (2004). A child's work: The importance of fantasy play. Chicago, University of Chicago Press.

Paugh, A. L. (2005). Multilingual play: Children's code-switching, role play, and agency in Dominica, West Indies. Language in Society, 34, 63-86, DOI: 10.10170S0047404505050037. www.jstor.org/stable/4169400

Pelligrini, A. (1982). Classroom contextual effects of children's play. Child Development, 25, 289-2996.

Pellegrini, A. (1984). Sociolinguistic contexts of the preschool. Journal of Applied Developmental Psychology, 4, 397405.

Pellegrini, A. D., \& Galda, L. (1993). Ten years after: A reexamination of symbolic play and literacy research. Reading Research Quarterly, 28(2), 163-175. doi:10.2307/747887

Piaget, J. (1962). Play, dreams and imitation in childhood. New York: Norton.

Puteh, S and Ali, A (2013). Malaysian Journal of Learning and Instruction, 10, 79-98.

Robles, J., (2009). The Role of Play in Second Language Acquisition: A Bilingual Grandmother and a Preschool Child. www.hamline.edu/WorkArea/DownloadAsset.aspx?id=2147491034

Roskos, K. A., Tabors, P. O., \& Lenhart, L. A. (2004). Oral language and early literacy in preschool: Talking, reading, and writing. Newark, DE: International Reading Association.

Scanlon, Donna M, Anderson, K. L, \& Sweeney, J. M. (2010). Early intervention for reading difficulties: the interactive strategies approach. The Guilford Press. New York

Singer D. G, Golinkoff R. M, \& Hirsh-Pasek K. (2006). Play = learning: how play motivates and enhances children's cognitive and social-emotional growth. Oxford University Press. New York. https://books.google.lk/

Smilansky, S, (1968). The effects of sociodramatic play on disadvantaged preschool children. New York: Wiley.

Smith, P. K. (2010). Understanding Children's Worlds: Children and Play. West Sussex: Wiley Blackwell.

Snow, C., Burns, M. S., \& Griffin, P. (1998). Preventing reading difficulties in young children. Washington, D.C.: National Academy Press.

Sullivan, P. (2000). Playfulness as mediation in communicative language teaching in a Vietnamese classroom. In J. P. Lantolf (Ed.), Sociocultural theory and second language learning, (pp. 115-32). Oxford: OUP.

Vygosky, L. (1966). Play and its role in mental development. Soviet Psychology, 5(3), 6-18.

Vygotsky, L.S. (1967). Play and its role in the mental development of the child. Soviet Psychology, 5(3), 6-18.

Vygotsky, L. (1978). Mind in society: The development of higher psychological processes. Cambridge, MA: Harvard University Press.

Vygotsky, L. (1986). The phenomenology of language acquisition. Cambridge, MA: Harvard University Press.

Weisberg, D. S.,Zosh, J. M., Hirsh-Pasek, K., \& Golinkoff, R. M. (2013). Talking It Up: Play, Language Development, and the Role of Adult Support. American Journal of Play, 6(1), 39-54. files.eric.ed.gov/full text/EJ1016058.pdf Yellin, D., Blake, M. E., \& Devries, B. A. (2004). Integrating the language arts. Scottsdale, AZ: Holcomb Hathaway. Zigler, Edward F., and Sandra J. Bishop-Josef. 2004. "Play under Siege: A Historical Overview.” In E. F. Zigler, D. G. Singer, \& S. J. Bishop-Josef (Eds.), Children's Play: The Roots of Reading, (pp. 1-13). ZERO TO THREE/National Center for Infants, Toddlers and Families. 